
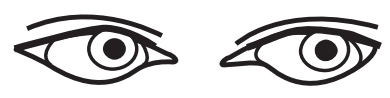

\title{
Vad händer när teori och praktik i socialt arbete integreras?
}

\author{
DIMITRIS MICHAILAKIS \\ \& WERNER SCHIRMER
}

\begin{abstract}
Det är inte lätt att säga något nytt eller originellt om förhaillandet mellan 'teori' och 'praktik'. (Börjeson, Börjeson, \& Svedberg, 2006, s.368)
\end{abstract}

\section{Introduktion}

Det finns ingen lärobok i socialt arbete som undkommer frågan om ämnets identitet, alltså vad socialt arbete är. Detta

Prof. Dimitris Michailakis

TEFSA - Plattformen för teorivägledd forskning i socialt arbete

Institutionen för Samhälls- och Välfärdsstudier

Linköpings Universitet

Docent Werner Schirmer

TEFSA - Plattformen för teorivägledd forskning i socialt arbete

Institutionen för Samhälls- och Välfärdsstudier Linköpings Universitet är en konsekvens av strävan att akademisera ämnet socialt arbete (Soydan, 1993; Dellgran \& Höjer, 2000). Det reflekteras i frågor om vad som är det gemensamma mellan så olika arbets- och forskningsområden såsom ungdomsbistånd, äldreomsorg, omsorg av personer med funktionsnedsättningar, sociala barn- och ungdomsvården, och vad är det som skiljer socialt arbete från grannämnen såsom pedagogik, psykologi, sociologi och socialmedicin. Oavsett vilka svar som ges så kan vi observera att som en röd tråd löper - nästan per automatik - ett återkommande tema, 
nämligen att ämnet socialt arbete både är en forskningsdisciplin (alltså det som kallas "teori") och en organiserad verksamhet som levererar hjälp och stöd till berättigade (alltså det som kallas "praktiken"). Det betonas av nästan alla att relationen mellan teori och praktik är på något sätt suboptimal (se t.ex.: Hessle, 1991; Dellgran \& Höjer, 2000; Brante, 2003; Bergmark \& Oscarsson, 2006; Börjeson, 2008). Exempelvis att det finns för lite relevans av det som forskarna håller på med för praktikerna, att det finns för lite samordning, att det råder bristfällig överföring från kunskap till handling m.m. Stål (1981) till exempel, menar att kopplingen mellan teori och praktik har diskuterats både i termer av att kunskap som produceras inom forskningen ska kunna omsättas i praktiken och omvänt att erfarenheter från praktiken ska utgöra grund för forskningen. Eller som EliassonLappalainen (2006, s. 319) har formulerat det poängfullt: "Ibland finns emellertid förhoppningen att forskningen också ska presentera direkta handlingsanvisningar, tekniker och lösningsmodeller. 'Nyttiga' resultat i betydelsen 'direkt tillämpbara' efterfrågas. En hel del forskare (dock inte alla) värjer sig mot det slags förväntningar."

Ingen i debatten förnekar vare sig betydelsen av forskning just för professionaliseringen och akademiseringen av yrkesfältet, å ena sidan, eller verksamheten av det organiserade hjälp och stödsystemet utan vilken det inte skulle finnas en forskningsdisciplin överhuvudtaget, å andra sidan. Ändå verkar det finnas en (åtminstone) latent konflikt mellan teorin och praktiken vad gäller tolkningsföreträdet om ämnets identitet (Blom, 1981; Lindholm \& Askeland, 1981; Dellgran \& Höjer, 2000; Bergmark \& Oscarsson, 2006; Nygren, 2006). Identitetsfrågan utspelar sig särskilt, och därmed reflektionen av teori- och praktikrelationen, inom den akademiska disciplinen. Enligt vår förståelse verkar de som jobbar "ute" i praktiken veta mycket väl vad de håller på med, och att identitetsfrågan knappast ställs. Kanske förhåller det sig på det viset eftersom de redan har "fullt upp" med sina arbetsuppgifter; med administrationen av hjälp och stöd samt med behandling av klienter.

Inom disciplinen socialt arbete, konstaterar vi, har två motstridiga positioner utkristalliserats som försöker lösa teori-praktik frågan på olika sätt. Den ena hävdar att det är hjälpsystemets, alltså praktikens behov som ska ligga till grund för vilka frågeställningar som ska prioriteras av forskningen (Swedner, 1981; Hessle, 1991). De andra anser att forskningen bör utvecklas autonomt från praktikens behov, och ansluter sig mera till vetenskapssystemet (Börjeson, 1984; Sunesson, 2003). Konfliktens kärna ligger i huruvida forskningen inom disciplinen socialt arbete ska utgå från inomvetenskapliga frågeställningar och behov av ny kunskap eller utgå från praktikens behov om hur man på bästa sätt kan åstadkomma förändring vad gäller klienternas situation (Lindholm \& Askeland, 1981).

Men inte ens i autonomipositionen kan man bortse ifrån att forskning $i$ socialt arbete ska ha någon slags - om inte direkt, så åtminstone indirekt - relevans för prak- 
tiken. Till syvende och sist är ändå socialt arbete ett akademiskt ämne som vuxit fram långt efter att det fanns en yrkesverksamhet.

Därmed är vi tillbaka till utgångspunkten, att identitetsfrågan om socialt arbete och teori-praktik-relationen är sammanvävda. För identitetens skull behövs alltså att man kommer fram till en viss lösning av konflikten mellan teori och praktik. De ord som används av båda positionerna för den eftersträvade lösningen är sådana som koppling, samordning och integration. Men vad är dessa ord uttryck för?

De som håller med praktikernas åsikt att akademin producerar för mycket som inte är användbart, de s.k. praktiknära forskarna, vill beakta praktikens behov och producera den kunskapen som praktikerna efterlyser. Samordning och integration skulle då, menar vi, i princip innebära att forskningen underordnas praktiken, och snarare bli uppdragsforskning till skillnad från det som de som ansluter sig till autonomipositionen förespråkar.

I spåren av debatten om evidensbaserad praktik (Bergmark \& Lundström, 2006; Bergmark, Bergmark, \& Lundström, 2011) har frågan om relationen mellan teori och praktik åter aktualiserats, bara denna gång med omvända företecken. Där kan man finna uttryck för uppfattningen att praktik som inte är evidensbaserad befinner sig i blåsväder, just eftersom den inte kopplas till forskningen. EBP-förespråkarna hävdar att praktisk relevant kunskap produceras bara när teori och rigid metodologi är involverade, när praktisk relevant information koordineras av forskningen. Med andra ord, det är inte brist på forskningens relevans för praktiken, utan tvärtom, praktikens ignorans inför forskningens fynd och dess relevans. Istället för intuition och professionell auktoritet ska enligt EBP-paradigmet socialtjänstens insatser styras på basis av vetenskaplig evidens. Uttryckt med skarpare ordalag bör praktiken nu följa det som forskningen föreskriver. Det är också ett sätt att samordna teori och praktik, men det är kanske inte det som den praktiskt arbetande professionen önskar (Månsson, 2000, 2001; Webb, 2001; Biesta, 2007; Blom, 2009; Otto, Polutta, \& Ziegler, 2009).

Vi argumenterar $i$ den här artikeln att $i$ båda av dessa positioner idealiseras modellen om kunskapsöverföring ${ }^{1}$ och att $i$ strävan efter att integrera, koppla eller samordna teori och praktik finns det faror, fallgropar och återvändsgränder, som måste diskuteras för att bedöma om man verkligen ska sträva efter detta mål. Relationen mellan teori och praktik är mycket mera komplex än vad dessa modeller antyder.

Med denna text tar vi därmed också explicit ställning för antagandet att forskning inom socialt arbete kan ha en viss operativ autonomi. Detta innebär förstås inte att vi uppmanar forskare att förbise praktikernas behov. Inte heller förnekar vi att forskning inom socialt

1 Man föreställer sig gärna som idealtyp att det finns tolkningsfri kunskap som forskarna kan komma fram till och som de sedan förmedlar vidare till användarna. Detta helst i form av siffror och tabeller som visar "så här är det". Forskarna tillhandahåller siffrorna och praktikerna lägger upp sitt arbete i enlighet med vad som föranleds av insamlat data. 
arbete ska ha relevans för användarna. Just det utgör ju till exempel skillnaden mellan disciplinerna socialt arbete och sociologi. Den senare saknar ett specifikt yrkesfält som socialarbetarna, trots alla interna skillnader, har. Det som vi vill argumentera för är dock att disciplinen socialt arbete ska kunna formulera sina egna forskningsproblem. För att öka status inom vetenskapsvärlden måste forskningen vara mer teori- och mindre behovsstyrd.

Vår argumentation har tre steg. Som vi ska visa i det följande finns det varken bara en teori/forskning eller bara en praktik, utan en mångfald av dessa. Vi argumenterar i nästa avsnitt att olika teoretiska paradigm medför sin egen föreställning av vad det sociala arbetets identitet är, vad socialarbetarens yrkesroll innebär, och därmed också vad praktiken ska handla om. Dessa föreställningar är ibland explicita, ibland implicita, men viktigast är att de skiljer sig avsevärt i den bild de har och ger av praktiken i socialt arbete. I avsnittet därefter visar vi med hjälp av Luhmanns teori om funktionell differentiering (Luhmann, 1982, 1989, 1997) att vetenskapen följer en annan operationslogik än hjälpsystemet, och därmed också att disciplinen socialt arbete (teori) är en annan än verksamheten socialt arbete (praktik). Det som skiljer systemen är att i det första råder en struktur av kognitiva förväntningar medan det andra struktureras av normativa förväntningar (Luhmann, 1995). I sista steget lägger vi ihop båda argumentationstrådarna och beskriver vår tolkning, vilken ifrågasätter idén om enkla överföringar mellan teori och prak- tik. För det första noterar vi risken med en överordning av antingen praktiken över teorin eller omvänt och, för det andra, ett undergrävande av ämnets multiparadigmatiska karaktär om ett paradigm tillåts bli dominerande i forskningen och i praktiken. Artikeln avrundas med några konkluderande tankar.

\section{Avsnitt 1: Mångfald av teorier, mångfald av praktiker}

Inrättandet av en akademisk disciplin med den explicit formulerade förväntningen att tillgodose den moderna hjälporganisationens behov av systematiserad kunskap om sociala problem - deras bakomliggande orsaker, hur problemen ska lösas, vilka konsekvenser olika lösningar har, etc. - har öppnat för en stor variation av konkurrerande teorier som gör anspråk på att uppfylla kunskapsbehovet. Läget inom det akademiska ämnet socialt arbete kan beskrivas som multiparadigmatiskt. Mångfalden av vetenskapsteoretiska paradigmer - positivism, behaviorism, hermeneutik, kritisk teori, kunskapssociologi, konstruktivism m.fl. - konkurrerar även här om de teorier och metoder som ska vägleda forskning om sociala problem och dessas behandling på individ- och gruppnivå. Många forskare har också pekat på ämnets mångfald av paradigm (se bara Lindqvist \& Nygren, 2006; Nygren, 2006). Det som däremot inte uppmärksammats tillräckligt är faktumet att det också finns en mångfald av praktiker. Därmed menar vi inte differentieringen av så olika praktiska arbetsfält som äldrevård, kriminalvård, 
biståndsbedömning, placering i fosterhem, etc. Det är trivialt. Det mindre triviala är att olika teoretiska ansatser (paradigm) innefattar specifika uppfattningar om hur det sociala arbetets praktik utformas. En mångfald av teoretiska ansatser medför därmed en mångfald av praktiker, just beroende på vad ansatsen utgår ifrån.

Termen det sociala arbetets praktik hänvisar i största allmänhet till den verksamhet av hjälp och stöd som utförs genom välfärdsstatliga organisationer och som riktas mot utsatta grupper. Men här upphör det som är gemensamt. De teoretiska ansatserna varierar $i$ ett antal parametrar om vad praktiken är. De parametrar som vi vill begränsa oss till här är: samhällssynen, synen på klienten (människosyn), typen av sociala problem, synen på uppgifterna i socialt arbete och på socialarbetarens roll. Innebörderna av de olika parametrarna är paradigmberoende och betingar ofta varandra. När det t.ex. gäller parametern "människosyn» finns teorier som beskriver människan som en egoistisk nyttomaximerare som är ansvarig för sina handlingar. Samtidigt finns det teorier som beskriver människan som en varelse som också drivs av altruism och där omständigheter runtomkring antas förklara hennes belägenhet där hon kan drabbas av förhållanden bortom hennes makt och kontroll (social miljö, ogynnsamma socioekonomiska betingelser, etc.). Den första människosynen implicerar att praktiken tillämpar restriktiva regler till hjälp - konsekvensen är att färre anses vara berättigade till hjälp och stöd - medan den andra implicerar empati och därför ökad benägenhet till hjälp. Det är en spe- ciell typ av praktik som utformas när det vägledande paradigmet för det sociala arbetets praktik är New Public Management vars inflytande har vuxit under de senaste decennierna. Det är en teori från och för marknadsekonomin - med värden som konkurrens, privat vinstintresse, individuella rationella val och individuellt ansvar. Här uppfattas samhället som en marknad och en klients livssituation som resultat av hennes prestationer. Klienten ses huvudsakligen som en tillfällig avvikelse som ska återföras på rätt kurs som deltagare på arbetsmarknad och andra marknader, dvs. som konsument. Det sociala problemet är inte social exklusion utan snarare brist på följsamhet och flexibilitet, avvikande beteende eller direkt motstånd mot systemet. Som en följd av denna uppfattning framstår socialarbetarens roll snarare som kontrollant än som en förmedlare av hjälp och stöd. Den motsatta uppfattningen kan vi finna i marxistiska ansatser i socialt arbete. Socialarbetaren ses inom dessa ansatser som en politisk aktör, vilken genom sina insatser ska motarbeta klassamhället på mikronivån genom att på klassiskt socialpedagogiskt vis uppmuntra klienten till klasskänsla och motstånd mot de förtryckande strukturerna. Klienten betraktas som ett offer för ett samhällssystem och hennes ogynnsamma livssituation ses som ett symptom enbart på det egentliga sociala problemet (konkurrens, exploatering, vinstorientering).

Varje paradigm implicerar en bestämd människosyn, samhällssyn, syn på rollen som socialarbetare och klient, syn på och syfte med intervention, kontroll, stöd, 
etc. Eftersom det är med utgångspunkt i och på grundval av paradigm som man ser mönster och samband om sociala problem, så kommer - beroende på vilka paradigm man utgår ifrån - innebörden i de begrepp och de modeller som man använder sig av att samvariera. Ett socialpolitiskt paradigmskifte på basis av socialvetenskapliga teorier innebär att socialt arbete ändrar sina syften, innebörder, rolldefinitioner och metoder: att det bedrivs på annat sätt, med andra premisser och målsättningar än tidigare. Därför är det missvisande att prata om det sociala arbetets praktik i singularis. Vi bör istället tala om det sociala

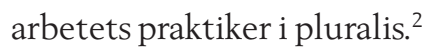

\section{Avsnitt 2: vetenskapssystemet och hjälpsystemet}

Brante (2003) har beskrivit relationen mellan teori och praktik som en relation mellan två olika praktiker (den teoretiska praktiken och det sociala arbetets praktik). Dessa praktiker genomsyras av två olika logiker som det gäller att förena (se också Hessle, 1991, s.72). Vi föredrar att tänka teori och praktik i socialt arbete - och detta ska förstås i sin pluralitet

2 Ett likande argument har gjorts av Nygren (2006, s.307): "under en trettioårsperiod har det sociala arbetet som praktikfält modifierats hela tiden, och att dess gränser varit allt annat än stabila. Nya målgrupper, ny ideologi, ny metodik, ny kunskap osv. har introducerats, och frågan om det ena eller det andra ska kallas 'socialt arbete' förefaller inte ha varit särskilt viktig". Nygren har dock inte gått hela vägen och dragit samma slutsatser som vi gör $\mathrm{i}$ avsnitt 3 . som kartlades i förra avsnittet - som en relation mellan två olika sociala system: vetenskapssystemet och hjälpsystemet. Även om de är olika sociala system står de inte nödvändigtvis i motsättning till varandra. En full överrensstämmelse mellan deras observationer och beskrivningar av ett fenomen är inte heller sannolik.

Hjälpsystemet och vetenskapen avgränsar sig från varandra genom att använda sig av systemspecifika kriterier för att selektera information om fenomen i deras omvärld (Luhmann, 1997). Hjälpkommunikation formerar sig kring klienters behov och selekterar information om behoven genom distinktioner behövande/ icke-behövande, berättigade/icke-berättigade till hjälp och slutligen hjälp/ickehjälp (La Cour, 2002). Hjälpsystemet kommunicerar med andra ord på basis av behovsbedömning om sina val om dessa behövande personer som klienter. Dessa val är dock inte val av den enskilde socialarbetaren. De är val av en kod som styrs av program och det är betydelselöst för systemet vem den konkreta individen är som genomför dessa val (Scherr, 1999; Luhmann, 2005[1973]; Wirth, 2009).

Vetenskapssystemet (där också forskningsdisciplinen socialt arbete ingår) kommunicerar förstås på ett helt annat sätt än hjälpsystemet. Här handlar det om att vinna ny kunskap i metodologiskt kontrollerade, helst teoridrivna undersökningsprojekt. Den vetenskapliga koden är således sant/falskt; det som räknas är sanning, inte det som är politiskt önskvärt. Kommunikationsformen är den vetenskapliga publikationen i facktid- 
skrifter - där gäller det tack vare peer-review-principen att man måste förhålla sig helt i linje med det som anses vara rimligt $\mathrm{i}$ vetenskapliga termer, alltså passande teori, förankring i respektive fälts diskurs av tidigare forskning och lämpligt metodval. Skillnaden till hjälpsystemet kunde inte vare större. Det blir också synligt med uttrycket "metod" som inom vetenskapssystemet avser någonting helt annat än inom hjälpsystemet.

Liksom andra funktionssystem (politik, rätt, ekonomi, religion) uppfyller vetenskap och hjälpsystemet specifika, säregna funktioner (Schirmer \& Michailakis, 2008) för samhället. Var och en av dem löser ett särskilt referensproblem. Forskningen syftar till att studera, analysera och skapa teorier om sociala problem. Forskningen orienterar sig mot kunskap. De medel som används är vetenskapliga kartläggningar av empiri och förklaringar med hjälp av teorier. Olika paradigm innebär att olika problem identifieras; olika beskrivningar genereras och olika lösningar föreslås.

Det sociala arbetets praktik (hjälpsystemet) syftar till att vidta åtgärder om sociala problem och till sitt förfogande har systemet medel såsom hjälp och stöd, interventioner, preventivt arbete mot exklusion (Schirmer \& Michailakis, 2013). Praktiken är alltid interventionsorienterad, oavsett människosyn och samhällssyn. Hjälpsystemet möjliggör för samhället att iaktta olika fenomen med utgångspunkt $\mathrm{i}$ och genom distinktionen hjälp/icke-hjälp. Det betyder att allt som får status i samhället som socialt problem omfattas potentiellt av hjälpens blick
(Appel Nissen, 2010). Det betyder vidare att de beskrivningar som hjälpsystemet tillhandahåller om fenomen som fattigdom, våld, rasism, prostitution, etc. är just beskrivningar som legitimerar interventioner. De är beskrivningar som tar fasta på behovet av organiserad hjälp.

Den funktionella differentieringen mellan disciplinen socialt arbete och praktiken, alltså den mellan vetenskapssystemet och hjälpsystemet innebär bland annat att systemen är autonoma och står $i$ ett horisontellt förhållande och inte $i$ ett vertikalt förhållande till varandra. I enlighet med Luhmanns samhällsteori behandlar vi - som redan har framgått teori och praktik som ekvivalenta uttryck för två autonoma system som är tvungna att oavbrutet ta in information om varandra. Praktiken iakttar de kunskaper som forskningen producerar och forskningen iakttar de interventioner (metoder, resultat, sekundära konsekvenser) som företas i praktiken. På grund av deras iakttagelser av varandra tvingas de att anpassa sina egna beskrivningar av fenomen. Det är alltså inte något kausalt förhållande eller ett förhållande av direkt styrning eller överföring som råder mellan vetenskapen och hjälpsystemet. Det är en relation av ömsesidig observation och varje förändring är varje systems egen prestation (se Schirmer \& Hadamek, 2007). Vare sig vetenskapssystemet kan bestämma hur och med vilka konsekvenser forskningsfynd uppfattas och tillämpas i det sociala arbetets praktiker eller hjälpsystemet kan fastlägga forskningsobjektet för disciplinen socialt arbete utan att skada dess autonomi. Autonomi och funktionell skil- 
jelinje mellan forskningen och praktiken får dock inte missförstås som ömsesidigt oberoende, eller autarki (Luhmann, 1989, 1997). ${ }^{3}$ Tvärtom, utan praktiken (och professionsutbildningen) har forskningen i socialt arbete svårt att avgränsa sig från t.ex. sociologi, psykologi eller pedagogik. Utan forskning i socialt arbete om sociala problem har praktiken svårt att avgränsa sig från välgörenhet, delar i polisens verksamhet, vissa uppgifter som utförs av sjukvårdspersonal, vakter, terapeuter etc. (Börjesson, 2008).

Vi har argumenterat att teori och praktik skiljer sig med avseende på funktion, systemrationalitet och observationssätt. I det följande ska vi argumentera för att dessa två system skiljer sig också med avseende på hur deras operationer (att forska respektive att hjälpa) struktureras. Luhmann (1995) uppfattar strukturen av ett socialt system som en uppsättning av förväntningar. ${ }^{4}$ Genom förväntningar begränsar systemen mångfalden av infor-

3 Det gäller förstås relationen mellan alla andra funktionssystem också. Inget system kan fungera om inte de andra också fungerar: Utan rättssystemet ingen kontraktsäkerhet, och därmed inga ekonomiska investeringar. Utan politisk makt ingen ny lagstiftning för rättssystemet, utan pengar, ingen välfärdsstat osv.

4 Som systemteoretikern Stichweh förklarar: "Social structures obviously consist from expectations. There is no other plausible candidate in systems theory. And expectations will have to be defined - and be distinguished from the fleetingness of individual communications - by characterizing them as generalizations of social meaning transcending a certain span of time and a certain diversity of individual perspectives"(Stichweh, 2005, s. 364). mation som kan införlivas i systemet, alternativt skapar nya möjligheter. Det som har införlivats i systemet avgör hur systemet kan förhålla sig till andra system i sin omvärld och därmed även vilka handlingar som personer som handlar utifrån dessa system kan företa. Relationen mellan systemen ska inte förstås kausalt, som något som om det ena systemet förorsakar effekter i det andra. Bägge systemen väljer själva vad i omvärlden ska beaktas och vad som ignoreras. Valet sker pga. bestämda förväntningar, samtidigt som systemet förblir indifferent för andra förväntningar. På detta sätt menar vi att förväntningar strukturerar vad som händer i respektive system.

Luhmann skiljer mellan normativa och kognitiva förväntningar. I varje system kan man finna förväntningar både av det ena och av det andra slaget. Men den relativa tyngdpunkten varierar. System som strukturerar sig själva och därmed sin relation till omvärlden med hjälp av normativa förväntningar kommer inte att förändra sin struktur även när dessa förväntningar inte går verkligheten till mötes. Förväntningarna förblir intakta även vid misslyckanden. Medan kognitiva förväntningar kan upprätthållas bara när de understöds av verkligheten. Strukturen i dessa system förblir intakt när förväntningarna visar sig vara berättigade, medan förväntningarna i annat fall revideras. Därför lär systemet av motgångar. Kognitiva förväntningar leder till kunskap eftersom man alltid är beredd att revidera det som inte visar sig stämma, medan normativa förväntningar är ett uttryck för strukturkonservatism, 
dvs. man ändrar inte en handlingsorientering även när verkligheten falsifierar den.

Ett socialt system kan alltså anpassa sig till den besvikelsen av missräknade förväntningar och lära sig av detta, men det kan också insistera på att de ska bekräftas trots upprepade besvikelser (rättssystemet är typexempel på detta - den normativa förväntningen att alla ska betala skatt ändras inte även vid omfattande skattefusk). Vilken inställning systemet väljer är viktigt eftersom den avgör dess beteende mot de "avvikelser" som uppstår mellan systemet och omvärlden (mellan vad som förväntas av systemet och hur omvärlden ter sig) och anpassar sin respons genom att skapa bredare eller snävare handlingsutrymme i sin relation till andra i omvärlden.

Vi menar att disciplinen socialt arbete och praktiken är två autonoma system som också skiljer sig på basis av skilda förväntningar: I hjälpsystemet är normativa förväntningar förhärskande medan i forskningen härskar kognitiva förväntningar. Praktikens normativa orientering och forskningens kognitiva orientering är konsekvensen av att sociala problem definieras som diskrepansen mellan vad som (och varför det) är och vad som man borde göra emot (Merton \& Nisbet, 1971). Den första adresseras av forskningen medan den andra adresseras av hjälpsystemet.

Vi påstår att de förväntningar som strukturerar hjälpsystemet står i samklang med samhällets förväntningar på hjälpsystemet, nämligen att det ska vidta åtgärder mot sociala problem, dvs. om förhållanden som inte borde finnas. Detta tvingar hjälpsystemet att förhålla sig normativt och inte kognitivt till sociala problem. Kort sagt, skillnaden mellan forskning och praktik är en skillnad mellan hur det är och hur det bör vara.

\section{Avsnitt 3: Autonomi eller över-/underordning?}

I Sverige inrättades ämnet med den explicita förväntningen att integrera forskningen och praktiken (se kungörelsen till de första professurerna i Sverige, citerade i Soydan, 1993, s. 32). I samma spår argumenterar även Hutchinson Strand \& Oltedal (2006) att socialt arbete faktiskt är ett sammansatt fält som konstitueras av både praktiskt socialt arbete, socialt arbete som utbildningsämne och socialt arbete som forskningsämne. Integrationsförespråkarna ser integration mellan teori och praktik som lösning på (1) hur informationen/kunskapen kan överföras från teori till praktik och omvänt, (2) dilemmat huruvida praktiken eller teorin ska definiera ämnets identitet. När man argumenterar för integration kan det innebära att man implicit eller explicit refererar till åtskillnader samt att man betraktar åtskillnader som ett potentiellt problem, som en potentiell konfliktkälla: integration har en positiv konnotation, och som konsekvens dess motbegrepp en negativ konnotation. Att det inte nödvändigtvis behöver vara så ska vi kommentera nedan där vi argumenterar för att integration sker på bekostnad av vetenskaps- och hjälpsystemets oberoende. 
Innan dess måste dock en annan aspekt framhållas: Teori-praktik-integration är möjlig, så länge man stannar inom samma paradigm, men det är ju inte heller önskvärt. Som framgått i avsnitt 1 har ämnet socialt arbete - både som forsknings- och som utbildningsverksamhet - karaktären av att vara multiparadigmatiskt dvs. ett brett, komplext, tvärvetenskapligt ämne som studerar sociala problem utifrån olika vetenskapliga paradigm (Jönson, 2010). Även om det ibland uppfattas som en nackdel (Dellgran \& Höjer, 2006) ser vi vinsten att sociala problem belyses från olika teorier. Det är en vinst om man utgår från att ingen teori är heltäckande och att det för alla teorier gäller att vissa aspekter görs synliga medan andra osynliggörs. Det är alltså något som en vetenskaplig disciplin snarare uppskattar. För den önskade integrationen av teori och praktik blir dock den multiparadigmatiska karaktären i ämnet snarare ett hinder. Vi menar att teori och praktik kan integreras, men det går på bekostnad av mångfalden av paradigm. Om bara ett paradigm skulle få göra sig gällande genom ett auktoritativt förklarande av alla andra som felaktiga, ideologiska eller olämpliga att hantera kunskapsmassan i det sociala arbetets teori och praktik - skulle teori och praktik kunna integreras, men det skulle ske genom att ämnets komplexitet skulle reduceras radikalt. Hypotetiskt talat: om New Public Management skulle bli allenarådande inom forskning och utbildning, skulle så småningom även praktiken strömlinjeformas utan mycket utrymme för variation. Det har kallats "scientific-bureaucratic model" (Harrison, Moran, \& Wood, 2002), till skillnad från en reflexiv praxis-modell. En sådan teori-praktik-integration vore alltså förknippad med stora kostnader för mångfalden både vad gäller forskning och praktik.

Tillbaka till frågan om integration av differentierade system: Om distinktionen integration/åtskillnad tas som utgångspunkt, vilket integrationsförespråkarna gör, och utgår ifrån att teori och praktik inte ska vara skilda åt utan att de ska integreras, står det i kontrast till uppfattningen att mellan forskning och praktik råder en funktionell skiljelinje. Integration, taget på allvar, innebär nämligen att skillnaden mellan två system - där den ena står för kunskapsproduktion och den andra för intervention - suddas ut. Och även om det skulle vara avsikten, kan man hävda att det är omöjligt att integrera skilda meningskontexter (Luhmann, 1995).

Det är underförstått för integrationspositionen att forskning som bidrar till att åtskillnaden mellan teori och praktik minimeras, ska föredras framför den som accentuerar åtskillnaden. Praktiknära forskning och EBP minimerar skillnaden mellan teori och praktik, vilket i båda fallen anses ha ett värde i sig - dock med omvända förtecken. Åtskillnaden kan nämligen minimeras på två sätt: antingen genom att praktikens specifika kunskapsbehov föreskriver forskningens problemdefinitioner (praktiknära forskning) eller att forskningen i enlighet med EBP-paradigmet föreskriver yrkesutövningen för praktiken. I det ena fallet underordnas vetenskapen, i det andra fallet underord- 
nas praktiken. Inget av fallen är tillfredsställande, menar vi.

För några år sedan efterlyste Thomas Brante"en teoretisk plattform där teori och praktik kan förenas" (Brante, 2003, s. 12). På teorinivå kan teori och praktik naturligtvis integreras. Men debatten ger anledning att tro att idén om integration hänvisar till en förening i den utomteoretiska verkligheten - alltså den mellan två system. Det menar vi varken är möjligt eller värt att sträva efter. Målet att teori och praktik bör integreras i realiteten kan bara utmynna i polarisering, eftersom om inte båda systemens operationssätt störs, påtvingas det ena systemets rationalitet det andra. Två skilda systemrationaliteter kan inte - utan stora störningar - förenas i en enhet (det framgår med all tydlighet i flera aktuella konflikter, t.ex. mellan det ekonomiska systemet och utbildningssystemet eller hälso- och sjukvården och det politiska systemet). Det är viktigt att inse att det handlar om två separata observationsperspektiv på sociala problem: forskningens och praktikens.

Integration och autonomi är, menar vi, två mål som står i konflikt med varandra. Ett socialt system som integreras med ett annat förlorar sin autonomi. $\AA$ ena sidan innebär integration av teori och praktik inskränkning för forskningens frihet vilket alltid varit en grundförutsättning för ett ämnes fortgående akademisering. När praktikens normativa förväntningar introduceras i forskningen sker det på bekostnad av dess autonomi, eftersom strävan efter kunskap underordnas dess praktiska användbarhet. I det långa loppet gynnas inte heller praktiken av detta sätt att instrumentalisera forskningen.
A andra sidan vill ingen heller föreställa sig en praktik som underkastas forskningsresultatens imperativ. När vetenskapens kognitiva förväntningar introduceras i praktiken kan detta ske på bekostnad av frihetsgrader i handlingsförmåga och professionell "discretionary power». Dessutom, om den komplexitet som karaktäriserar forskningen påtvingas praktiken, kommer dess flexibilitet och effektivitet att bli ordentligt kringskuren. Det skulle också hindra hjälpsystemet att bygga/bibehålla sin egen (praktiska) komplexitet. I bägge fallen leder integration till heteronomi dvs., osjälvständighet och en utifrån kommande styrning.

Det grundläggande problemet är alltså att den akademiska friheten inte ska försvaras på bekostnad av praktiken eller omvänt att praktikens effektivitet inte ska ske på bekostnad av forskningens autonomi. Målet bör vara att rädda integriteten (autonomin) hos båda. De bör utvecklas i jämvikt istället för hierarkiskt. Vi argumenterar därför att teori och praktik inte ska tänkas som konkurrenter utan som resurser för varandra.

Om distinktionen autonomi/heteronomi tas som utgångspunkt, istället för integration/autonomi öppnar sig ett annat perspektiv. Forskning och praktik är inte bara högt differentierade sociala system med egen logik som selekterar och skapar information utifrån helt olikartade koder (falsk/sann, intervenera/icke-intervenera, berättigad/oberättigad till hjälp och stöd), som inte står i ett hierarkiskt förhållande till varandra som system. Autonomi kan, menar vi, ses som ett positivt värde - till skillnad från integration - och är dessu- 
tom i linje med hur det moderna samhället är strukturerat dvs. genom differentiering i olika funktionssystem som står i ett horisontellt förhållande till varandra.

\section{Slutord}

Vi har i denna artikel argumenterat att forskning och praktiken inte kan integreras (annat än inom teorin), utan att samtidigt skada antingen de olika områdenas autonomi, eller mångfalden av paradigm som karakteriserar både forskning och praktik. Inom debatten råder enighet om att forskning och praktik är konstitutiva för ämnet socialt arbete. Men det innebär ingenting annat än att ämnet är en hybrid, på samma sätt som psykologi eller medicin är det, som har var sin forskningssida och var sin praktiska sida. Det är viktigt att beakta den funktionella skiljelinjen mellan dem. Med Luhmanns systemteori kan vi förklara att forskning och praktik tillhör skilda funktionssystem - trots sin hybrida existens inom fältet socialt arbete. Dessa system, vetenskapssystemet (forskning) och hjälpsystemet (praktiken), fungerar enligt olika logiker som strukturerar sina operationer genom två i grunden oförenliga förväntningar: kognitiva respektive normativa. Att integrera dem skulle antingen skada båda systemens operationssätt eller inordna det ena under det andra, dvs. påtvinga det ena systemets program och förväntningsstrukturer på det andra. Integration av teori och praktik innebär då begränsning av minst ett systems autonomi. Detta argument mot integration skulle vi därför kunna kalla «autonomiargumentet».

Det andra sättet att lösa integrationsproblemet vore att ge företräde åt ett paradigm (av de många paradigmen inom socialt arbete) på bekostnad av de andra. Integration mellan forskning och praktik skulle då uppnås eftersom det finns teoriparadigm som definierar var "sin" praktik. Såvitt vi vet har ingen explicit föreslagit något sådant. Socialvetenskapen lär oss att i ett komplext samhälle blir forskningen om sociala problem nästan per automatik multiparadigmatisk eftersom själva de sociala problemen ifråga är multidimensionella, dvs. de ser olika ut beroende på vem som observerar dem (Michailakis \& Schirmer, 2014). Att skapa integration genom att överordna ett paradigm de andra eller till och med selektera bort de andra kan anses som hot mot mångfalden. Den typen av argument mot integration kan vi därför kalla "mångfaldsargumentet".

Både autonomiargumentet och mångfaldsargumentet siktar emot integration och värnar för det som, enligt vår mening, skulle gynna ämnet socialt arbete, dess praktik och dess forskning (båda i pluralis), och slutligen utbildningen mest, nämligen att autonom forskning och autonom praktik liksom en mångfald av teoriparadigm kan vara resurs för varandra. Resurs är inte detsamma som instrument. Instrument för tankarna till hierarki av medel och mål (de sista kan också endast definieras utifrån en hierarkiskt överordnad position).

Avslutningsvis några tankar om identitetsfrågan i socialt arbete eftersom den 
är så nära knuten till frågan om relationen mellan teori och praktik. I enlighet med autonomiargumentet menar vi att: (1) Man måste hålla isär frågan "Vad är kärnan i socialt arbete som ett forskningsämne?" från frågan "Vad är kärnan i det sociala arbetets praktik?". Forskningsämnet och det sociala arbetets praktik kan inte sammanfalla pga. den funktionella skiljelinjen mellan de två. (2) Ämnets identitet etableras genom att accentuera differensen mellan forskning och praktik, inte genom att söka efter hur de kan integreras. Forskningen måste avgränsa sig från praktiken och ansluta sig till vetenskapen för att skapa anseende och status som en vetenskap bland andra med ett distinkt forskningsobjekt; en strävan som också prak- tiken skulle gynnas av. Samma statusproblem som det sociala arbetets forskare har bland sina kollegor från andra akademiska discipliner upplever också det sociala arbetets praktiker i samarbetet med psykologer, läkare och pedagoger (Sommerfeld, 2000).

Identitetsfrågan kan lösas på ett helt annat sätt än genom att integrera teori och praktik. Det kan till och med ske på det eleganta sätt som den tyske socialarbetsforskaren och praktikern Heiko Kleve formulerar det: Socialt arbete är på grund av sin stora mångfald av teoriparadigm, praktiska interventionsformer och stora flexibilitet en disciplin "utan egenskaper" (Kleve, 2007). Och detta ser han förstås inte som brist utan som resurs! 


\section{Referenser}

Appel Nissen, M. (2010). Nye horisonter $i$ socialt arbejde: en reflektionsteori. Köpenhamn: Akademisk Forlag.

Bergmark, A., Bergmark, Å., \& Lundström, T. (2011). Evidensbaserat socialt arbete: Teori, kritik, praktik. Stockholm: Natur \& Kultur.

Bergmark, A., \& Lundström, T. (2006). Mot en evidensbaserad praktik? - Om färdriktningen i socialt arbete. Socialvetenskaplig tidskrift, 13(2), 99-113.

Bergmark, A., \& Oscarsson, L. (2006). Att utveckla, sammanställa och tillämpa kunskaper i socialt arbete. In A. Meeuwisse, S. Sunesson \& H. Swärd (red.), Socialt arbete. En grundbok (s. 405-422). Stockholm: Natur \& Kultur.

Biesta, G. (2007). Why "what works" won't work: Evidence-based practice and the democratic deficit in educational research. Educational theory, 57(1), 1-22.

Blom, A. (1981). Forskning i socialt arbete - några synpunkter. In K. Lindholm \& K. Askeland (Eds.), Vad är socialt arbete? (s. 231-239). Stockholm:Liber.

Blom, B. (2009). Knowing or un-knowing? That is the question in the era of evidence-based social work practice. Journal of Social Work, 9(2), 158-177.

Börjeson, B. (1984). Om socialt arbete som ett kunskapsområde (Vol. 24). Institutionen för socialt arbete. Umeå universitet.

Börjeson, B., Börjeson, M., \& Svedberg, L. (2006). Att utveckla kunskapen i socialt arbete genom att återigen sätta praktiken i centrum. In A. Meeuwisse, S. Sunesson \& H. Swärd (red.), Socialt arbete. En grundbok (s. 368-384). Stockholm: Natur \& Kultur.

Börjeson, B. (2008). Förstå Socialt Arbete. Stockholm:Liber.

Brante, T. (2003). Konsolideringen av nya vetenskapliga fält. Exemplet forskning i social arbete. In Högskoleverket (red.), Socialt arbete. En nationell genomlysning av ämnet. Högskoleverkets Rapportserie 2003:16R (s. 133-196).
Stockholm:Högskoleverket.

Dellgran, P., \& Höjer, S. (2000). Kunskapsbildning, akademisering och professionalisering $i$ socialt arbete. Diss., Göteborgs universitet, Göteborg. Dellgran, P., \& Höjer, S. (2006). Pluralism på gott och ont? Om forskningen och den akademiska kunskapsproduktionen i socialt arbete. In A. Meeuwisse, S. Sunesson \& H. swärd (red.), Socialt arbete. En grundbok. (s. 348-367). Stockholm: Natur \& Kultur.

Eliasson-Lappalainen, R. (2006). Om olika vägar till kunskap. In A. Meeuwisse, S. Sunesson \& H. Swärd (red.), Socialt arbete. En grundbok (s. 319-333). Stockholm: Natur \& Kultur.

Harrison, S., Moran, M., \& Wood, B. (2002). Policy emergence and policy convergence: the case of 'scientific-bureaucratic medicine'in the United States and United Kingdom. The British Journal of Politics \& International Relations, 4(1), 1-24.

Hessle, S. (1991). Nätverksforskning i praktiken Barnbyn Skå som modell. In H. Berglind \& P.-O. Kristenson (red.), Socialt arbete i utveckling (s. 69-87). Stockholm: Allmänna förlaget.

Hutchinson Strand, G., \& Oltedal, S. (2006). Modeller $i$ socialt arbejde. København: Hans Reitzel.

Jönson, H. (2010). Sociala problem som perspektiv. En ansats för forskning \& socialt arbete. Malmö: Liber.

Kleve, H. (2007). Postmoderne Soziale Arbeit. Ein systemtheoretisch-konstruktivistischer Beitrag zur Sozialarbeitswissenschaft. Wiesbaden: VS-Verlag.

La Cour, A. (2002). Frivillighedens pris: en undersøgelse af Niklas Luhmanns teori om sociale systemer og dens anvendelse på området for frivilligt socialt arbejde. Köpenhamn: Köpenhamns Universitet.

Lindholm, K., \& Askeland, K. (red.) (1981). Vad är socialt arbete? Stockholm: Liber.

Lindqvist, R., \& Nygren,L. (2006). Social teori och socialt arbete. In A. Meeuwisse, S. Sunesson \& 
H. Swärd (red.), Socialt arbete. En grundbok (s. 94-109). Stockholm: Natur \& Kultur.

Luhmann, N. (1982). The Differentiation of Society. New York: Columbia University Press.

Luhmann, N. (1989). Ecological Communication. Chicago: University of Chicago Press.

Luhmann, N. (1995). Social Systems. Palo Alto: Stanford University Press.

Luhmann, N. (1997). Die Gesellschaft der Gesellschaft. Frankfurt/Main: Suhrkamp.

Luhmann, N. (2005[1973]). Formen des Helfens im Wandel gesellschaftlicher Bedingungen. In N. Luhmann. Soziologische Aufklärung 6. (red.), (s. 167-186).Wiesbaden:VS-Verlag.

Månsson, S.-A. (2000). Kunskapsutvecklingen inom socialtjänsten och den akademiska forskningen: drar vi åt samma håll? Socionomen(8), 4-9.

Månsson, S.-A. (2001). Nationellt stöd för kunskapsutvecklingen inom socialtjänsten. Socionomen(3), 18-21.

Michailakis, D., \& Schirmer,W.(2014). Social work and social problems: A contribution from systems theory and constructionism. International Journal of Social Welfare, 23(4), 431-442.

Merton, R. K., \& Nisbet, R. (red.). (1971). Contemporary social problems. New York: Harcourt Brace Jovanovich.

Nygren, L. (2006). Socialt arbete som ämne. In A. Meeuwisse, S. Sunesson \& H. Swärd (red.), Socialt arbete. En grundbok (s. 303-318). Stockholm: Natur \& Kultur.

Otto, H.-U., Polutta, A., \& Ziegler, H. (red.). (2009). Evidence-based Practice - Modernising the Knowledge Base of Social Work. Opladen \& Farmington Hills: Barbara Budrich.

Scherr, A. (1999). Transformations in social work: from help towards social inclusion to the management of exclusion. European Journal of Social Work, 2(1), 15-25.

Schirmer, W., \& Hadamek, C. (2007). Steering as Paradox. The Ambiguous Role of the Political
System in Modern Society. Cybernetics and Human Knowing, 14(2), 133-150.

Schirmer, W., \& Michailakis, D. (2008). Intersektionalitet och systemteori (s. 185-214). M. Söder \& L.Grönvik (red.) Bara funktionshindrad? Funktionshinder och intersektionalitet. Malmö: Gleerups.

Schirmer, W., \& Michailakis, D. (2013). The Luhmannian approach to exclusion/inclusion and its relevance to Social Work. Journal of Social Work, forthcoming. doi: 1468017313504607

Sommerfeld, P. (2000). Soziale Arbeit als sekundäres Primärsystem und der ,very strange loop" sozialarbeiterischer Profis. In R. Merten (red.), Systemtheorie Sozialer Arbeit (s. 115136). Opladen: Leske+Budrich.

Soydan, H. (1993). Det sociala arbetets idéhistoria. Lund:Studentlitteratur.

Stål, R. (1981). Om socialt arbete, kunskap och handling. In K. Lindholm \& K. Askeland (red.), Vad är socialt arbete? (s. 221-230). Stockholm: Liber.

Stichweh, R. (2005). The Present State of Sociological Systems Theory. In J. M. Santos (red.), O Pensamento de Niklas Luhmann (s. 347-371). Covilhã: Universidade da Beira Interior.

Sunesson, S. (2003). Socialt arbete - en bakgrund till ett forskningsämne. In Högskoleverket (red.), Socialt arbete. En nationell genomlysning av ämnet. Högskoleverkets Rapportserie 2003:16R (s. 75-132). Stockholm: Högskoleverket.

Swedner, H. (1981). Ämnet socialt arbete - ett svar på ett rop från fältet. In K. Lindholm \& K. Askeland (red.), Vad är socialt arbete? (s. 242260). Stockholm: Liber.

Webb, S. A. (2001). Some considerations on the validity of evidence-based practice in social work. British Journal of Social Work, 31(1), 57-79.

Wirth, J. (2009). The Function of Social Work. Journal of Social Work, 9(4), 405-419. 